\begin{tabular}{c}
\hline \hline Juntendo \\
Research Profiles \\
\hline \hline Juntendo Medical Journal \\
2015. 61 (2), 182-183
\end{tabular}

\title{
Emergency Medicine in Juntendo Hospitals
}

Four of the Juntendo Hospitals have a Department of Emergency Medicine: Hongo, Shizuoka, Urayasu, and Nerima. At Hongo and Urayasu Hospitals, both clinical research and basic research are undertaken, while at Shizuoka and Nerima Hospitals, clinical study is the main focus. Currently, each department performs research work independently; however, work involving collaboration between different Juntendo hospitals will be initiated in the near future. Here, we introduce the current status of the research work in each hospital.

\section{I ) Research Profiles in Juntendo Hongo Hospital Director: Professor Toshiaki Iba \\ Research Theme (Basic) :}

1. Neutrophil extracellular traps (NETs) and cell death

This is a collaborative study with Clinical Laboratory Medicine and the Department of Host Defense and Biochemical Research, Juntendo University (for details, see ref. \#1,2).

2. Circulating damage-associated molecular patterns and their proteomic analysis in severe sepsis

This is a collaborative study with the Department of Bioscience and Biotechnology, Tokyo Institute of Technology (for details, see ref. \#3).

Research Theme (Clinical) :

3. The treatment of disseminated intravascular coagulation (DIC) (for details, see ref. \#4).

4. The treatment of thrombosis using factor $\mathrm{Xa}$ inhibitors

This is a collaborative study with the Department of Orthopedic Surgery, Juntendo University (for details, see ref. \#5).

\section{References}

1) Iba T, Miki T, Hashiguchi N, Tabe Y, Nagaoka I: Is the neutrophil a 'prima donna' in the procoagulant process during sepsis? Critical Care, 2014; 8: 230.

2) Iba T, Miki T, Hashiguchi N, Yamada A, Nagaoka I: Combination of antithrombin and recombinant thrombomodulin attenuates leukocyte-endothelial interaction and suppresses the increase of intrinsic DAMPs in endotoxemic rats. J Surg Res, 2014; 187: 581-586.

3) Iba T, Miki T, Hashiguchi N, Tabe Y, Nagaoka I: Combination of antithrombin and recombinant thrombomodulin modulates neutorophil cell-death and decreases circulating DAMPs levels in endotoxemic rats. Thromb Res, 2014; 134: 169-173.

4) Iba T, Gando S, Thachil J: Anticoagulant therapy for sepsis-associated disseminated intravascular coagulation- The View from Japan. J Thromb Haemost, 2014;
12: $1010-1019$.

5) Iba T, Aihara K, Yamada A, Nagayama M, Tabe Y, Ohsaka A: Rivaroxaban attenuates leukocyte adhesion in the microvasculature and thrombus formation in an experimental mouse model of type 2 diabetes mellitus. Thromb Res, 2014; 133: 276-280.

\section{II) Research Profiles in Juntendo Shizuoka Hospital} Director: Professor Youichi Yanagawa

The Department of Acute Critical Care Medicine, Shizuoka Hospital, Juntendo University, manages a level I emergency and critical care center. This hospital is located on Izu Peninsula surrounded by the Pacific Ocean, which is a resort area popular for its hot springs, beautiful coastline, beaches, mild climate, and scenic mountainous interior. A World Heritage Site, Mount Fuji, lies only about 50 kilometers to the north. We treat patients with cardiopulmonary arrest, trauma, anaphylaxis, intoxication, convulsion, unconsciousness, and unstable vital signs. Our department also manages the emergency medical system of physician-staffed emergency helicopters (HEMS) and the helicopter parks at our hospital (Figure-1). We mainly perform clinical study concerning the patients we have treated. We introduce some recent original reports of our clinical study below ${ }^{1-5}$.

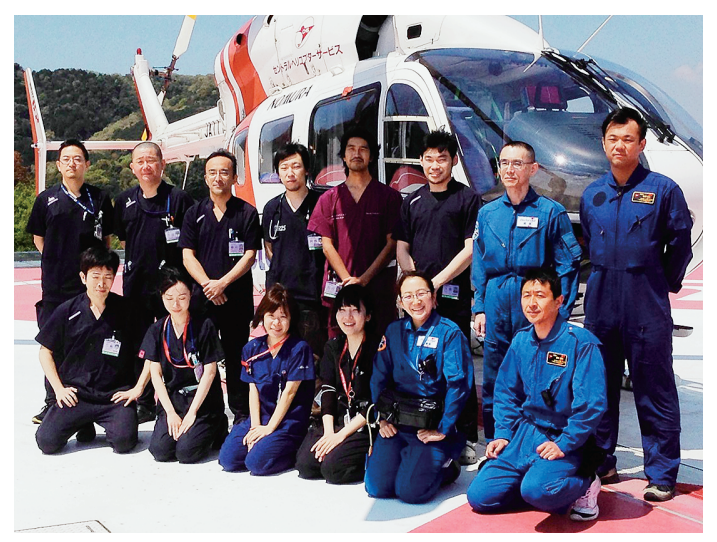

Figure-1

\section{References}

1) Omori K, Ohsaka H, Ishikawa K, Obinata M, Oode Y, Kondo A, Kanda A, Fujii M, Sakurada M, Nakao Y, Suwa T, Okamoto K, Yanagawa Y: Introduction of a physician-staffed helicopter emergency medical service in eastern shizuoka prefecture in Japan. Air Med J, 2014; 33: $292-295$. 
2) Omori K, Ishikawa K, Obinata M, Mishima K, Fukusato S, Ohsaka H, Oode Y, Yanagawa Y: Significance of the vacuum phenomenon in patients with trauma evaluated by whole-body computed tomography. Am J Emerg Med, 2015; 33: 282-285.

3) Ohsaka H, Omori K, Obinata M, Ishikawa K, Oode Y, Yanagawa Y: Analysis of trauma cases after a record snowfall in a rural district in Japan. J Emerg Trauma Shock, 2014; 7: 341.

4) Yanagawa Y, Omori K, Obinata M, Ohsaka H, Ishikawa K, Kitamura S, Kitagawa Y, Ihara Y: Significance of hypernatremia following the correction of severe hyperglycemia. Am J Emerg Med, 2014; 32: 800-801.

5) Ishikawa K, Omori K, Obinata M, Mishima K, Osaka H, Oode Y, Kubota A, Sakuraba K, Yanagawa Y: A field survey of spinal cord injury in bodyboarders. Am J Emerg Med, 2015; 33: 112-113.

III) Research Profiles in Juntendo Urayasu Hospital Director: Professor Hiroshi Tanaka

\begin{tabular}{|c|c|}
\hline Researcher & Research theme \\
\hline \multirow[t]{2}{*}{ Prof. Okamoto K } & $\begin{array}{l}\text { Optimized preparation for hospital } \\
\text { function in a disaster }\end{array}$ \\
\hline & $\begin{array}{l}\text { The efficacy of triage with support- } \\
\text { ing devices in the emergency room }\end{array}$ \\
\hline \multirow[t]{2}{*}{ Associate Prof. Inoue Y } & $\begin{array}{l}\text { A development study for novel } \\
\text { biomarkers to evaluate the severity } \\
\text { of inhalation injury }\end{array}$ \\
\hline & $\begin{array}{l}\text { Clarification of the infection route of } \\
\text { Acinetobacter baumannii in patients } \\
\text { involved in motor vehicle accidents }\end{array}$ \\
\hline \multirow[t]{2}{*}{ Associate Prof. Sumi Y } & ATP/adenosine balance in SIRS \\
\hline & $\begin{array}{l}\text { The risk factors of VTE in pelvic } \\
\text { fracture patients }\end{array}$ \\
\hline Clinical fellow Nishiyama K & $\begin{array}{l}\text { Development of patients' dashboard } \\
\text { system for communication and safety }\end{array}$ \\
\hline Clinical fellow Sueyoshi K & $\begin{array}{l}\text { Visualization of ATP in sepsis } \\
\text { patients' PMNs with organelle-local- } \\
\text { izable fluorescent chemosensors }\end{array}$ \\
\hline Clinical fellow Oono $\mathrm{K}$ & $\begin{array}{l}\text { Electrogastrography in critical care } \\
\text { patients }\end{array}$ \\
\hline Assistant Prof. Morikawa M & $\begin{array}{l}\text { The utilization of methylxanthine } \\
\text { for asthma exacerbation in Japa- } \\
\text { nese emergency departments }\end{array}$ \\
\hline Clinical fellow Fukumoto Y & $\begin{array}{l}\text { Application to triage of blood lac- } \\
\text { tate level }\end{array}$ \\
\hline \multirow[t]{2}{*}{ Clinical fellow Takizawa S } & $\begin{array}{l}\text { Successful treatment of Boerhaave } \\
\text { syndrome by conservative therapy }\end{array}$ \\
\hline & $\begin{array}{l}\text { Role of emergency physicians sta- } \\
\text { tioned in mass-gathering area }\end{array}$ \\
\hline Clinical fellow Ishihara $\mathrm{T}$ & EAA analysis in pediatric patients \\
\hline Clinical fellow Nakamura Y & $\begin{array}{l}\text { The radiographic findings of post- } \\
\text { cardiac arrest syndrome }\end{array}$ \\
\hline Clinical fellow Suginaka M & Safety precautions for children \\
\hline Clinical fellow Maki C & $\begin{array}{l}\text { The clinical outcome of critical care } \\
\text { patients with sivelestat sodium }\end{array}$ \\
\hline Graduate student Murata K & Heart rate variability in sepsis patients \\
\hline Graduate student Wada Y & $\begin{array}{l}\text { Appropriate airway management } \\
\text { in out-of-hospital cardiopulmonary } \\
\text { arrest patients }\end{array}$ \\
\hline
\end{tabular}

Publications (in English, 2014 2015)

1) Sumi $Y$, Woehrle T, Chen Y, Bao Y, Li X, Yao Y, Inoue Y, Tanaka H, Junger WG: Plasma ATP is required for neutrophil activation in a mouse sepsis model. Shock, 2014; 42: 142-147.

2) Suginaka H, Okamoto K, Hirano Y, Fukumoto Y, Morikawa M, Oode Y, Sumi Y, Inoue Y, Matsuda S, Tanaka H: Hospital disaster response using business impact analysis. Prehosp Disaster Med, 2014; 29: 561568.

3) Ohara K, Inoue Y, Sumi Y, Morikawa M, Matsuda S, Okamoto K, Tanaka H: Oxidative stress and heart rate variability in patients with vertigo. AMS, 2014. In press.

4) Morikawa M, Hagiwara A, Sakamoto T, Kimura A: Blunt cardiac injury with scintigraphic perfusionmetabolism mismatch. AMS, 2014; 1: 58-60.

5) Morikawa M, Inoue Y, Sumi Y, Kuroda Y, Tanaka H: Leukocyte deformability is a novel biomarker to reflect sepsis-induced disseminated intravascular coagulation. AMS, 2015; 2: 13-20.

\section{IV) Research Profiles in Juntendo Nerima Hospital Director: Associate Professor Manabu Sugita References}

1) Tagami T, Tosa R, Omura M, Fukushima H, Kaneko T, Endo T, Rinka H, Murai A, Yamaguchi J, Yoshikawa K, Saito N, Uzu H, Kase Y, Takatori M, Izumino H, Nakamura T, Seo R, Kitazawa Y, Sugita M, Takahashi H, Kuroki Y, Irahara T, Kanemura T, Yokota H, Kushimoto $\mathrm{S}$ : Effect of a selective neutrophil elastase inhibitor on mortality and ventilator-free days in patients with increased extravascular lung water: a post hoc analysis of the PiCCO Pulmonary Edema Study. J Intensive Care, 2014; 2: 67.

2) Tagami T, Nakamura T, Kushimoto $S$, Tosa R, Watanabe A, Kaneko T, Fukushima H, Rinka H, Kudo D, Uzu H, Murai A, Takatori M, Izumino $\mathrm{H}$, Kase $\mathrm{Y}$, Seo R, Takahashi H, Kitazawa Y, Yamaguchi J, Sugita M, Takahashi H, Kuroki Y, Kanemura T, Morisawa K, Saito $\mathrm{N}$, Irahara $\mathrm{T}$, Yokota H: Early-phase changes of extravascular lung water index as a prognostic indicator in acute respiratory distress syndrome patients. Ann Intensive Care, 2014; 4: 27.

3) Kaneko T, Kawamura Y, Maekawa T, Tagami T, Nakamura T, Saito N, Kitazawa Y, Ishikura H, Sugita M, Okuchi K, Rinka H, Watanabe A, Kase Y, Kushimoto S, Izumino H, Kanemura T, Yoshikawa K, Takahashi H, Irahara T, Sakamoto T, Kuroki Y, Taira Y, Seo R, Yamaguchi J, Takatori M; PiCCO Pulmonary Edema Study Group: Global end-diastolic volume is an important contributor to increased extravascular lung water in patients with acute lung injury and acuterespiratory distress syndrome: a multicenter observational study. J Intensive Care, 2014; 2: 25. 